\title{
Stress among medical students of Gorgan (South East of Caspian Sea), Iran
}

\author{
Marjani A ${ }^{1}$, Gharavi AM², Jahanshahi $\mathbf{M}^{2}$, Vahidirad $\mathbf{A}^{3}$, Alizadeh $\mathbf{F}^{3}$ \\ ${ }^{1}$ Associated Professor, Faculty of Medicine, Golestan University of Medical Sciences, Biochemistry and Metabolic \\ Disorder Research Center; ${ }^{2}$ Faculty of Medicine, Department of Anatomy; ${ }^{3}$ medical student, Gorgan Faculty of Medicine, \\ Golestan University of Medical Sciences, Gorgan, Iran.
}

\begin{abstract}
Objective: This study aims to estimate the prevalence of psychological stress and association between the levels of stress and study variables among Gorgan medical students.

Materials and methods: All three year medical students (129 basic sciences students) in Gorgan Faculty of Medicine, Golestan University of medical Sciences, were asked to complete the Kessler 10 questionnaire.

Results: The findings showed mild, moderate and severe stress among $26.22 \%, 20.50 \%$ and $14.75 \%$ study subjects. $39.35 \%$ of medical students had no stress. There was statistically significant association between year of study and stress levels $(\mathrm{p}=0.040)$.

Conclusion: The results indicate that there is a decrease in the psychological health of first year medical students. Provided that stress management courses are organised by medical schools, when the students arrive, they will cope up with the stress in coming years. These courses may reduce the negative effects of stress on medical students. By providing such courses and reducing stress level, medical students may improve their medical education.
\end{abstract}

Key words: Medical students, stress, Gorgan

$\mathrm{M}$ edical students are subjected to many psychological changes. Many studies have shown high rates of psychological morbidity in medical students at various stages of their training ${ }^{1,2,3}$. There is growing appreciation of the stresses involved in medical training. Studies which have examined sources of stress among medical students generally points to three main areas: academic pressures, social issues and financial problems ${ }^{4}$. It is suggested that the greatest stress occurs during the later years of medical education ${ }^{5,6,7}$, while Guthrie et al found that the percentages of students who had psychological morbidity were very similar in years 1 and $4^{8}$. However Stewart et al indicated that in year 2, medical students had higher scores of anxiety and depression than in year $1^{9}$. Studies have observed that medical students experience a high incidence of personal distress during their undergraduate course. High levels of stress may have a negative effect on mastery of the academic curriculum. Stress, health and emotional problems increase during the period of undergraduate medical education. This can lead to mental distress and has a negative impact on cognitive functioning and learning ${ }^{10}$. Study of Firth in three British universities showed that the prevalence of stress was $31.2 \%{ }^{1}$. Study of Sherina et $\mathrm{al}^{11}$ and Saipanish ${ }^{12}$ showed that the prevalence of stress was $41.9 \%$ and $61.4 \%$ in a Malaysian and Thai medical school respectively. Medical school stress is likely to predict later mental health problems, but students seldom seek help for their problems ${ }^{13}$. Dahlin et al showed that the prevalence of depressive symptoms among Swedish students was $12.9 \%$ and a total of $2.7 \%$ of students had made suicidal attempts ${ }^{10}$. It is important for medical educators to pay attention and know the prevalence and causes of students' distress, which not only affects his health, but also their academic achievement at different time points of their study period, the present study was undertaken to estimate the prevalence of psychological stress and association between the levels of stress and study variables (academic year, regular to course and physical problems) among Gorgan medical students.

\section{Materials and methods}

All the three year medical students (129 basic sciences students) in the Gorgan Faculty of Medicine were

\footnotetext{
Correspondence

Abdoljalal Marjani,

Faculty of Medicine,

Golestan University of Medical Sciences,

Biochemistry and Metabolic Disorder Research Center,

Gorgan, IRAN

E-mail: abdoljalal@yahoo.com
} 
asked to complete the Kessler 10 self-administrated Persian version questionnaire during the academic year 2008. At this time of study, Golestan province has only one medical school, Golestan University of Medical Sciences, which has a six-year study programme. The first two and half years are largely pre-clinical years (basic sciences) and are grounding in basic human sciences such as anatomy, physiology and biochemistry; and in the later clinical years students have clinical rotations through the healthcare facilities (hospitals and polyclinics). Questionnaires were given to medical students to fill, a month before beginning of the examination period to minimise the extra stress symptoms. The students were allowed to respond in their own time and privacy. The Kessler10 Psychological Distress (K10) has been developed by Kessler and colleagues, to measure current (1-month) distress. It has been designed to measure the level of distress and severity associated with psychological symptoms in population surveys. The K10 comprises 10 questions of the form, "how often in the past month did you feel ..." and offers specific symptoms such as "tired out for no good reason," "nervous", and "sad or depressed". The five possible responses range from "none of the time" to "all of the time" and are scored from 1 to 5; the items are assumed to obtain a total score. A score of less than 20 was considered not to represent a 'case' possibility of mental disorder. A score of 20-24 was considered to present a mild stress, 25-29 was considered to present moderate stress and $\geq 30$ was considered to represent as severe stress. These coding were used according to the instructions of the authors14. Data were entered using SPSS version 11.5 statistical software. Prevalence of an outcome variable along with $95 \%$ confidence interval was calculated. Pearson's chi-square test and odds ratio were used to observe and quantify an association between the categorical outcome and different study variables. Student's t-test for independent samples was used to compare the mean values of study variables in relation to stress. A p-value of less than 0.05 was considered statistically significant. The outcome variable stress was categorized into dichotomous as stress (no/yes) by considering the three levels (mild, moderate and severe) of stress as presence of stress.

\section{Results}

A total of 122 out of 129 student population completed and returned the questionnaires. The overall response rate was $94.57 \%, 91.83 \%(n=45)$ in first year, 97.91 $\%(n=47)$ in second year and $93.75 \%(n=30)$ in third year. The mean age of study sample was $20.27 \pm 1.15$ years. The prevalence of stress of all types was found to be about $61.47 \%$. The prevalence of stress among medical students is shown in Table 1 . The distribution of academic year, regular to academic course and physical problems are shown in Table 2. The prevalence of stress was higher $(73.33 \%)$ in first year of study followed by second year $(55.31 \%)$ and third year $(53.33 \%)$. There is statistically significant association between the year of study and the stress levels. As the year of study increased, the prevalence of stress decreased, which is statistically significant $\left(\mathrm{X}^{2}=6.452, \mathrm{p}=0,040\right)$. The odds ratios (OR) 2.615 (first year) and 0.969 (second year), when third year is considered as reference category also indicates statistically significant association. The odds of student having stress is higher in first year, where as the odds are decreasing in second year as shown in table3. There is no statistically significant association between the regularity (Yes/No) to the academic course and the stress levels of study subjects. The distribution of stress levels is not significantly different, being a student either regular or irregular to the academic course $\left(\mathrm{X}^{2}=0.271\right.$, $\mathrm{p}=0.603)$. The corresponding odds ratios also show non significant association $(\mathrm{OR}=0.785,95 \%$ Confidence Interval (C.I.): 0.315-1.957). The prevalence of physical problems is not statistically significantly associated with the stress levels $\left(\mathrm{X}^{2}=0.690, \mathrm{p}=0.406\right)$. The OR 0.717 shows the odds of getting into stress is lower with mild to moderate and severe physical problems when compared with no physical problems as shown in table 4.The mean number of days unable to work (4.47 days) was higher in subjects who had stress, when compared with the subjects with no stress (2.31 days) which is statistically significant $(t=2.79, \mathrm{p}=0.0060)$. The mean number of days cut down (3.41 days) was higher in subjects, who had stress, when compared with subjects with no stress (1.77 days) which is statistically significant $(t=3.08, p=0.0030)$. 
Table 1: Distribution of stress levels among medical students

\begin{tabular}{|l|c|c|}
\hline & Number & Percent (\%) \\
\hline Not stressed & 47 & 39.35 \\
\hline Mild & 32 & 26.22 \\
\hline Moderate & 25 & 20.50 \\
\hline Severe & 18 & 14.75 \\
\hline Total & $\mathrm{n}=122$ & $100 \%$ \\
\hline
\end{tabular}

Table 2: Distribution of academic year, Regular to academic course and physical problems among medical students

\begin{tabular}{|l|c|c|}
\hline & Number & Percent (\%) \\
\hline Academic level $(\mathrm{n}=122)$ & & 36.88 \\
\hline First year & 45 & 38.52 \\
\hline Second year & 47 & 24.60 \\
\hline Third year & 30 & \\
\hline $\begin{array}{l}\text { Regular to academic } \\
\text { course( } \mathrm{n}=122)\end{array}$ & & 18.85 \\
\hline Yes & 23 & 81.15 \\
\hline No & 99 & \\
\hline Physical problems $(\mathrm{n}=122)$ & & 71.31 \\
\hline No & 87 & 28.69 \\
\hline Mild to moderate & 35 & 0 \\
\hline Severe & 0 & \\
\hline
\end{tabular}

Table 3: Association of stress and year of study

\begin{tabular}{|l|c|c|c|c|c|}
\hline $\begin{array}{l}\text { Academic } \\
\text { year }\end{array}$ & $\begin{array}{c}\text { Stress No (\%) } \\
\text { No }\end{array}$ & $\begin{array}{c}\text { Stress No (\%) } \\
\text { Yes }\end{array}$ & $\begin{array}{c}\text { Odds Ratio } \\
(\mathbf{O R})\end{array}$ & $\mathbf{9 5 \%}$ CI & P-value \\
\hline First year & $12(26.67)$ & $33(73.33)$ & 2.615 & $1.010-6.774$ & 0.048 \\
\hline Second year & $21(44.69)$ & $26(55.31)$ & 0.969 & $0.384-2.443$ & 0.946 \\
\hline Third year & $14(46.67)$ & $16(53.33)$ & $1 *$ & - & - \\
\hline
\end{tabular}

$\mathrm{X}^{2}=6.452, \mathrm{p}=0,0401^{*}=$ baseline

Table 4: Association between stress and regular to academic course and physical problems

\begin{tabular}{|c|c|c|c|c|c|}
\hline & $\begin{array}{c}\text { Stress No }(\%) \\
\text { No }\end{array}$ & $\begin{array}{c}\text { Stress No }(\%) \\
\text { Yes }\end{array}$ & $\begin{array}{l}\text { Odds Ratio } \\
\text { (OR) }\end{array}$ & $95 \% \mathrm{CI}$ & P-value \\
\hline \multicolumn{6}{|c|}{$\begin{array}{l}\text { Regular to academic } \\
\text { course }(n=122)^{1}\end{array}$} \\
\hline Yes & $10(8.20)$ & $13(10.65)$ & 0.785 & $0.315-1.957$ & 0.603 \\
\hline No & $49(40.16)$ & $50(40.99)$ & 1 & - & \\
\hline \multicolumn{6}{|l|}{$\begin{array}{l}\text { Physical problems } \\
(\mathrm{n}=122)^{2}\end{array}$} \\
\hline No & $40(32.80)$ & $47(38.52)$ & 1 & - & \\
\hline Mild to moderate & $19(15.57)$ & $16(13.11)$ & 0.717 & $0.326-1.575$ & 0.407 \\
\hline Severe & 0 & 0 & 0 & 0 & 0 \\
\hline
\end{tabular}

${ }^{1}: \mathrm{X}^{2}=0.271, \mathrm{p}=0.603,{ }^{2}: \mathrm{X}^{2}=0.690, \mathrm{p}=0.406$ 


\section{Discussion}

The response rate of $94.57 \%$ renders an adequate sample of the population studied. This study confirmed that there is considerable amount of stress in medical students at Gorgan medical school. Stress was found to be more in first year medical students rather than second and third years. Overall prevalence of stress in this study is $61.47 \%$ which is similar to the Thai ${ }^{12}$ and Saudi Arabia ${ }^{15}$ study: $61.4 \%$ and $57 \%$, respectively but higher than Malaysian (41.9\%) ${ }^{11}$ and British study $(31.2 \%){ }^{1}$. This study showed that the level of stress decreases as the year of study increases. The results of this study are in agreement to the results of a study where students found medical course stressful during the first year but not in subsequent years ${ }^{8,12,15}$. Our results could be explained by many factors. Medical students in Gorgan may need to be provided more time and facilities recreation and sports. Inadequate social activity was linked to impaired psychological health among medical students ${ }^{16}$, and that leisure activities can reduce stress in medical schools ${ }^{17}$. Although these facilities were available in our medical school adequate by the students. Medical students also may be able to cope stress with the help of our student support center. The other reason for stress could be due to excessive load of basic science subjects. Medical students must pass the basic science exams to be able to continue the pre-clinical study. In Iran education is free and small amount of monthly stipend is given to each student during their study (it is funded by the Ministry of Health Education), while in other foreign medical schools, students are plagued by financial worries, which is an important cause of their stress ${ }^{18}$.The length of medical courses provide the adverse effect on the psychological status of medical students which have been reported in many studies. Study in United Kingdom showed that one third of psychologically ill students did not graduate from the college ${ }^{19}$. This change probably is significant during first year of medical education. Medical student can refer to student consultancy center to prevent possible_future illness. Our results suggest that first year students who have higher level of stress should be supported by student consultancy center as they may be able to cope up with stress in later years. Medical schools in the United States and Canada have started health promotion programmes and have reported positive results in reducing the negative effects of stress upon medical student's health and academic performance $20,21,22$.

\section{Conclusion}

The results indicate that there is a decrease in the psychological health of first year medical students, provided that stress management courses are organized by medical schools. When students arrive, they will cope up with the stress in coming years. These courses may reduce the negative effects of stress on medical students. By providing such courses and reducing stress level, medical students may improve their medical education.

\section{Acknowledgment}

The authors would like to thank the first, second and third year students of Faculty of Medicine, Golestan University of Medical Sciences for providing the data for this article study.

\section{References}

1. Firth J. Levels and sources of stress in medical students. BMJ. 1986; 292:1177-80.

2. Miller PMcC, Surtees PG. Psychological symptoms and their course in first-year medical students as assessed by the Interval General Health Questionnaire (I-GHQ). Br J Psychiatr.1991; 159:199-207.

3. Guthrie EA, Black D, Shaw CM, Hamilton J, Creed FH, Tomenson B. Embarking upon a medical career: psychological morbidity in first year medical students. Med Educ. 1995; 29:337-41.

4. Vitaliano PP, Russo J, Carr JE, Heerwagen JH. Medical school pressures and their relationship to anxiety. J Nerv Ment Dis .1984; 172:730-6.

5. Alexander DA, Haldane JD. Medical education: a student perspective. J Med Educ. 1979; 13:3641.

6. Huebner LA, Royer JA, Morrel J. The assessment and remediation of dysfunctional stress in medical students. J Med Educ. 1981; 56:547-8.

7. Helmers KF, Danoff D, Steinert Y, Leyton M, Young SN. Stress and depressed mood in medical students, law students, and graduate students at McGill University. Acad Med. 1997; 72:708-14.

8. Guthrie E, Black D, Bagalkote H, Shaw C, Campbell M, Creed F. Psychological stress and burnout in medicalstudents: a five-year prospective longitudinal study. J R Soc Med. 1998; 91:237-43.

9. Stewart SM, Betson C, Marshall I, Wong CM, Lee PWH, Lam TH. Stress and vulnerability in medical students. Med Educ. 1995; 29:119-27.

10. Dahlin M, Joneborg N, Runeson B. Stress and depression among medical students: a crosssectional study. Med Educ. 2005; 39:594-604.

11. Sherina MS, Rampal L, Kaneson N. Psychological stress among undergraduate medical students. Med J Malaysia. 2004; 59:207-11. 
12. Saipanish R. Stress among medical students in a Thai medical school. Med Teach. 2003; 25 (5):502-6.

13. Tyseen R, Vaglum P, Gronvold, NT, Bkeberg O. Factors in medical school that predict postgraduate mental health problems in need of treatment. A nationwide and longitudinal study. Med Edu. 2001; 35:110-20.

14. Kessler RC, Andrews G, Colpe LJ, Hiripi E, Mroczek DK, Normand SL, et al. Short screening scales to monitor population prevalences and trends in non-specific psychological distress. Psychol Med. 2002; 32(6):959-76.

15. Hamza Mohammad Abdulghani. Stress and depression among medical students: A cross sectional study at a medical college in Saudi Arabia.Pak J Med Sci.2008;24 (1): 12-7.

16. Aktekin M, Karaman T, Senol YY, Erdem S, Erengin H, Akaydin M. Anxiety, depression and stressful life events among medical students: a prospective study in Antalya, Turkey. Med Educ. 2001; 35:12-7.
17. Shaikh B, Kahloon A, Kazmi M, Khalid H, Nawaz K, Khan N, Khan S. Students, stress and coping strategies: a case of Pakistani medical school. Educ Health (Abingdon). 2004; 17:34653.

18. Gushae J. Financial worries part of education for Memorial's medical students. Can Med Assoc J. 1997; 157(5):559-62.

19. Salmons PH. Psychiatric illness in medical students. Br J Psychiatry. 1983; 143:505-8.

20. Abramovitch H, Schreier A, Koren N. American medical students in Israel: Stress and coping-a follow-up study. Med Edu 2000; 34:890-6.

21. Lee J, Graham A. Students' perception of medical school stress and their evaluation of a wellness elective. Med Ed. 2001; 35:658-9.

22. Wolf TM, Randall HM, Faucett JM. A survey of health promotion programs in U.S. and Canadian Medical Schools. Am J Health Promot. 1988; 3:33-6. 